\title{
Article \\ Carbon Management behind the Ambitious Pledge of Net Zero Carbon Emission-A Case Study of PepsiCo
}

\author{
Duan Qian, Paul Dargusch (1) and Genia Hill *
}

check for

updates

Citation: Qian, D.; Dargusch, P.; Hill, G. Carbon Management behind the Ambitious Pledge of Net Zero

Carbon Emission-A Case Study of PepsiCo. Sustainability 2022, 14, 2171. https://doi.org/10.3390/su14042171

Academic Editor: Baojie He

Received: 12 January 2022

Accepted: 10 February 2022

Published: 14 February 2022

Publisher's Note: MDPI stays neutral with regard to jurisdictional claims in published maps and institutional affiliations.

Copyright: (C) 2022 by the authors. Licensee MDPI, Basel, Switzerland. This article is an open access article distributed under the terms and conditions of the Creative Commons Attribution (CC BY) license (https:// creativecommons.org/licenses/by/ $4.0 /)$.

\author{
School of Earth and Environmental Sciences, The University of Queensland, St Lucia, QLD 4072, Australia; \\ d.qian@uqconnect.edu.au (D.Q.); p.dargusch@uq.edu.au (P.D.) \\ * Correspondence: genia.hill@uq.edu.au
}

\begin{abstract}
Since the industrial revolution, greenhouse gas emissions caused by human activities have posed an unprecedented global challenge to social development and impact on the natural environment. With the growing awareness of environmental protection and the promotion of international cooperation mechanisms, there is a global consensus to control greenhouse gases In order to avoid irreversible and catastrophic climate change, there is an urgent need for more companies to take action and make credible commitments to combat climate change and carbon reduction goals aligned with the Paris Agreement and the UN Sustainable Development Goals. As one of the largest and most influential international food and beverage companies with a range of well-known brands, PepsiCo has made ambitious commitments to science-based climate goals, including reducing GHG emissions from its direct operations by $75 \%$ against the 2015 baseline and reducing GHG emissions across its indirect value chain by $40 \%$ by 2030 , as well as setting an ambitious new target to achieve net-zero emissions by 2040. PepsiCo has incorporated carbon reduction and climate strategies in all focus areas across its value chain, accelerating its work on broadening the scale of sustainable agriculture and regenerative farming practice; reducing plastic use and increasing the use of recycle and renewable materials as well as adopting low-carbon alternatives; developing efficient and alternative solutions in transportation and distribution; shifting to renewable electricity and fuels in manufacturing and fleet. Up to 2021, PepsiCo has achieved a $23 \%$ of the absolute emissions target of reducing Scope 1 and Scope 2 emissions and $7.9 \%$ of the absolute emissions target of reducing Scope 3 emissions. This research aims to evaluate the performance of PepsiCo on achieving their carbon reduction targets based on the analysis of the reported carbon estimates and reduction strategies, and also provides future strategic suggestions and guidance by adopting case study analysis. Although PepsiCo has reported great progress in reducing carbon emissions, further efforts are needed to achieve these goals.
\end{abstract}

Keywords: net zero; corporate sustainability; climate change mitigation; environmental, social, and corporate governance (ESG)

\section{Introduction}

Anthropogenic activity, especially the large-scale consumption of fossil fuels in the process of industrialization in developed countries, has led to a dramatic rise in the concentration of greenhouse gases in the atmosphere. According to an IPCC report, global warming is likely to reach $1.5^{\circ} \mathrm{C}$ between 2030 and 2052 if it continues to increase at the current rate (high confidence) [1]. The significant effects of global warming on natural systems and social development have been detected in varying degrees in the last 50 years [1], which poses an unprecedented challenge to the ecological environment and development of human society.

International cooperation on climate change has made significant progress through the introduction and improvement of a series of international climate policies [2]. The Paris Agreement 2015 provides a global framework with an explicit long-term goal to limit global 
warming to well below pre-industrial levels of 2 degrees Celsius, preferably 1.5 degrees Celsius [2]. Most countries have put effort into international climate change cooperation and enhanced their capacity to implement the Agreement. A range of ambitious actions and strategies have been carried out to address climate issues and enhance adaptation and resilience to related adverse impacts [2,3].

The Paris Agreement 2015 incorporates the emission reduction actions committed to by all parties into a unified and legally binding framework, prompting more and more countries, cities, and firms to establish and achieve net zero emission targets [3]. One of the prioritised actions indicated by the Paris Agreement 2015 is the science-based economic and social transformation [4]. Enormous firms and organisations pay more attention to their carbon footprint and to gradually transforming and adjusting their energy and industrial processes in response to the goal of international or national climate policies and increasing public environmental awareness [5]. Carbon footprints are used to quantify the environmental impact of carbon emissions at organisation-level from daily energy consumption, accounting for all direct emissions (Scope 1), indirect energy emissions (Scope 2) and other indirect emissions (Scope 3) within the set system boundaries and limits of the assessment. After assessing the carbon emissions of the entire value chain, enterprises can formulate corresponding emission reduction targets and strategies [6].

As interest in greenhouse gas emissions continues to rise among customers, government agencies and other stakeholders, many leading companies are motivated to improve the capacity of understanding their carbon footprint across the value chain by engaging their suppliers, customers, and other partners to incorporate the reduction of GHG emissions into their own business system practices and seek feasible and effective methods to reduce emissions $[5,7]$.

As a multinational company known for its consumer-facing brands, PepsiCo is dedicated to establishing a more sustainable food system through strengthening their capacity on tackling climate-related issues and carbon emission reduction. They recognise that committing to the environmental sustainability of their products and promoting this function to consumers can be a great contributor to their success in the marketplace, with a significant advantage over their competitors [8]. PepsiCo incorporates sustainability goals and strategies into the implementation of a range of initiatives. They target focus areas of the complex value chain to improve the energy efficiency of operations to reduce greenhouse gas emissions, achieve sustainable water security, innovate products, and recycle packaging materials. PepsiCo discloses their carbon emission estimates by scope and source, demonstrating their progress and outcomes. Meanwhile, they ensure that the company is adapting sustainability strategy in alignment with stakeholder expectations, legislation, and marketplace conditions $[7,9]$.

\section{Overview of the Firm}

More than one billion consumers in more than 200 countries and territories around the world enjoy PepsiCo products every day. More than 290,000 employees work in the firm. PepsiCo's portfolio of brands includes a range of popular food and beverage products, 23 of which have estimated annual retail sales of more than $\$ 1$ billion. The net revenues for PepsiCo in 2020 exceeded $\$ 70$ billion [9].

PepsiCo is committed to establishing a sustainable food system. They aim to take advantage of their scale, influence, and expertise to change the way the world produces, distributes, consumes, and handles food and drink to meet the global challenges brought by climate change, soil erosion, water scarcity, and population growth. The sustainability agenda of PepsiCo indicates six prioritised focus areas and goals in their sustainable food system, which include (1) agriculture (further expand the scale of sustainable agriculture and regenerative practices to improve agricultural resilience and reduce emissions); (2) water (promote water safety, ensure business continuity and make a positive contribution to the community); (3) packaging (promote "a world where packaging never becomes waste"); (4) products (optimize the product by reducing the addition of sugar, sodium and 
saturated fat); (5) climate (reduce greenhouse gas (GHG) emissions throughout the value chain; dedicate to the containment of climate change); (6) people (promote the provision of fair and safe working conditions and the establishment of an equitable and inclusive workplace) [9].

\section{Pledges and Targets}

PepsiCo announced the goal to reduce their absolute emissions across their entire value chain by $20 \%$ by 2030 (against a 2015 baseline) in 2016 . This goal has been approved by the Science-Based Targets Initiative (SBTi) and is aligned to a $2{ }^{\circ} \mathrm{C}$ pathway. In early 2020, PepsiCo announced the new ambition to reduce greenhouse gas emissions from its direct value chain (Scope 1 and 2) by 75\% from the 2015 benchmark and reduce greenhouse gas emissions from its indirect value chain (Scope 3) by 40\% [10]. As one of the 115 signatories of The Climate Pledge 2021, PepsiCo also pledged to achieve carbon neutrality by 2040, which is 10 years earlier than called for in the Paris Agreement [10]. PepsiCo committed to (1) regularly provide reports of greenhouse gas emission estimates; (2) develop and undertake low-carbon strategies consistent with the Paris Agreement through practical business change and innovation; (3) neutralize any remaining carbon emissions through additional, quantifiable, real, permanent, and socially beneficial offsets to achieve the goal of net-zero carbon emission by 2040 [11]. They are monitoring the guidance currently being developed by the SBTi and will align the target accordingly [12].

\section{Emissions Estimates}

PepsiCo discloses comprehensive financial information and carbon emission estimates and publishes them in their response to the CDP (Customer Data Platform) climate questionnaire annually (Table 1). The standard, protocol, or methodology have been applied to access activity data and calculated emissions are clearly stated [12].

\subsection{Scope 1 and Scope 2}

Region-specific emissions factors were applied to estimate the Scope 1 emissions from manufacturing operations and company-owned fleet fuel use in 2019 and 2020. Default emissions factors were applied in 2018. The 2017 report did not include emissions related to commercial activities in direct operations as part of the global total Scope 1 figure [12].

Table 1. Global gross Scope 1 emission categorised by business activities [12].

\begin{tabular}{|c|c|c|c|c|}
\hline Activity & $\begin{array}{c}2017 \text { Emissions } \\
\left(\text { Metric Tons } \mathrm{CO}_{2} \text { e) }\right.\end{array}$ & $\begin{array}{c}2018 \text { Emissions } \\
\text { (Metric Tons } \mathrm{CO}_{2} \text { e) }\end{array}$ & $\begin{array}{c}2019 \text { Emissions } \\
\text { (Metric Tons } \mathrm{CO}_{2} \text { e) }\end{array}$ & $\begin{array}{c}2020 \text { Emissions } \\
\left(\text { Metric Tons } \mathrm{CO}_{2} \text { e) }\right.\end{array}$ \\
\hline Processing/manufacturing & & $2,170,323$ & $2,167,540$ & $2,239,964$ \\
\hline $\begin{array}{l}\text { Distribution of } \\
\text { commodity }\end{array}$ & & $1,406,944$ & $1,384,874$ & $1,312,742$ \\
\hline Total & $3,734,520$ & $3,577,267$ & $3,552,415$ & $3,552,706$ \\
\hline
\end{tabular}

PepsiCo disclosed the breakdowns of gross global Scope 2 emissions by business division (Table 2). PepsiCo stated the electricity supplier emissions factors or residual emissions factors for some divisions are not accessible currently. They have applied and reported all available data (e.g., in Europe) to market-based Scope 2 emissions estimates. PepsiCo has in addition applied location-based methodology to estimate Scope 2 emissions. Therefore, they can evaluate and monitor the impact of the abatement efforts across different business activities and operational areas based on these two methodologies [12].

From Figure 1 above, a steady decline in Scope 1 and Scope 2 (market-based) can be observed over the past 4 years. There was a slight increase in Scope 2 emissions (locatedbased) in 2020, however, the total gross global Scope 2 emissions are on a downward trend. 
Table 2. Total gross global Scope 2 emissions by business division in 2020 [12].

\begin{tabular}{ccc}
\hline Business Division & $\begin{array}{c}\text { Scope 2, Location-Based } \\
\text { (Metric Tons CO } \mathbf{C}_{\mathbf{2}} \text { ) }\end{array}$ & $\begin{array}{c}\text { Scope 2, Market-Based } \\
\text { (Metric Tons CO }_{\mathbf{2}} \text { e) }\end{array}$ \\
\hline Africa, Middle East and South Asia & 419,016 & 419,016 \\
Asia Pacific, Australia and New Zealand, and China & 87,062 & 85,393 \\
Europe & 290,672 & 206,232 \\
Frito-Lay North America & 316,792 & 25,546 \\
Latin America & 183,545 & 100,951 \\
PepsiCo Beverages North America & 321,286 & 8,189 \\
PepsiCo Global Concentrate Solutions & 12,059 & 10,937 \\
Quaker Foods North America & 89,177 & 1134 \\
\hline
\end{tabular}

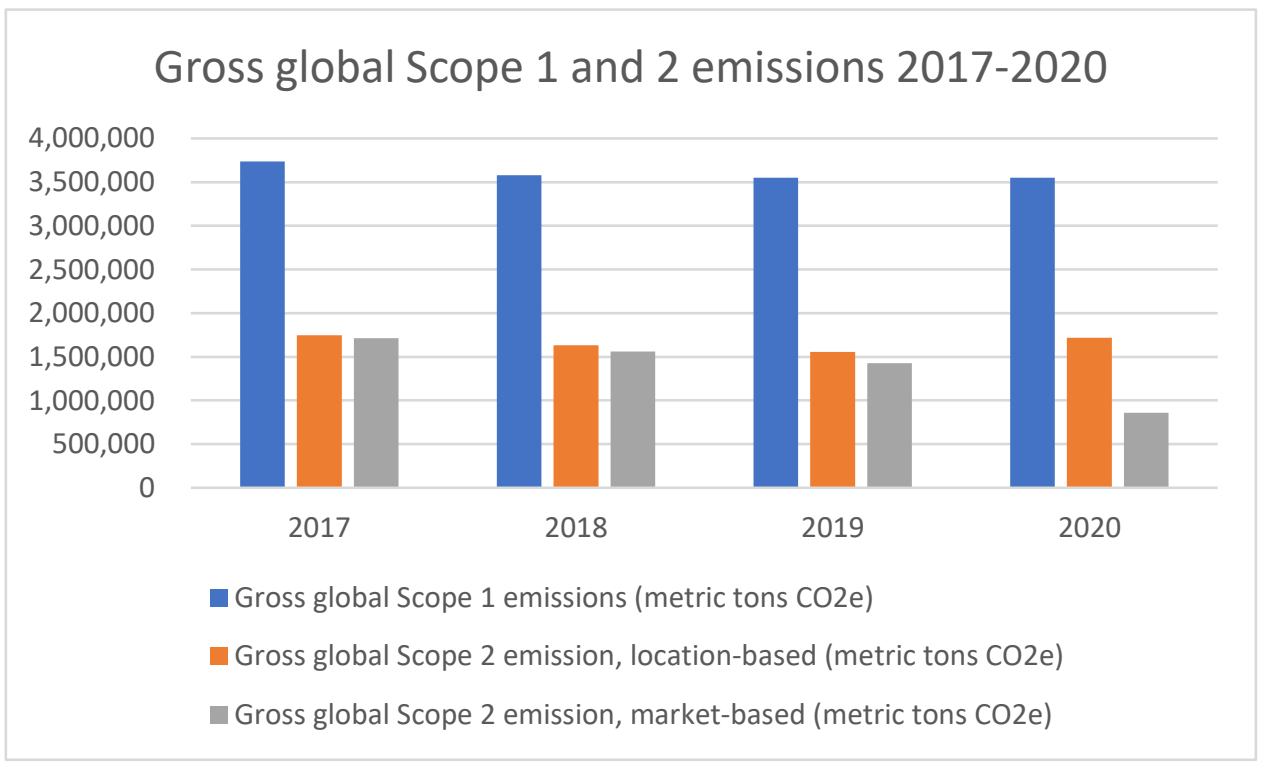

Figure 1. Gross global Scope 1 and 2 emissions 2017-2020 [12-14].

\subsection{Scope 3}

Scope 3 emissions contribute to approximately $93 \%$ of the total carbon emissions across the value chain [5]. PepsiCo disclosed the Scope 3 emissions breakdown based on relevant business activity areas across the value chain.

Table 3 provides robust evidence for the company to determine where it should focus most of its efforts. The decline of Scope 3 emissions can be observed in some business activity areas. However, the Scope 3 emissions are still increasing in several sectors due to business expansion, which contribute to the total increase in gross global Scope 3 emissions in 2020 (Figure 2). Emissions associated with some sources that contributed less than 1\% of overall Scope 3 emissions were not calculated based on an analysis [12]. Some examples of emission calculation methods and formulas according to GHG Protocol Scope 3 Standard are displayed in Appendix A.

Table 3. Scope 3 emissions breakdown by relevant business activity area in 2018-2020 [12-14].

\begin{tabular}{|c|c|c|c|}
\hline Source & 2020 & 2019 & 2018 \\
\hline Purchased goods and services & $36,519,067$ & $33,599,797$ & $39,026,490$ \\
\hline Capital goods & 989,112 & 600,278 & $1,698,930$ \\
\hline $\begin{array}{l}\text { Fuel-and-energy-related activities (not included } \\
\text { in Scope } 1 \text { or 2) }\end{array}$ & $1,566,238$ & 946,616 & 603,560 \\
\hline Upstream transportation and distribution & $1,773,024$ & 720,951 & $1,161,810$ \\
\hline Waste generated in operations & 48,947 & 25,353 & 60,360 \\
\hline Business travel & 137,668 & 140,452 & 121,070 \\
\hline Employee commuting & 150,635 & 201,663 & 506,710 \\
\hline Downstream transportation and distribution & $10,240,708$ & $11,088,559$ & $9,964,010$ \\
\hline Processing of sold products & 223,702 & 231,426 & $3,046,900$ \\
\hline End of life treatment of sold products & $1,179,467$ & 811,130 & $1,195,840$ \\
\hline Franchises & $1,651,219$ & $1,843,424$ & $1,418,720$ \\
\hline Investments & 148,986 & 255,417 & $2,730,730$ \\
\hline Other (downstream) & 0 & 0 & $1,282,850$ \\
\hline
\end{tabular}




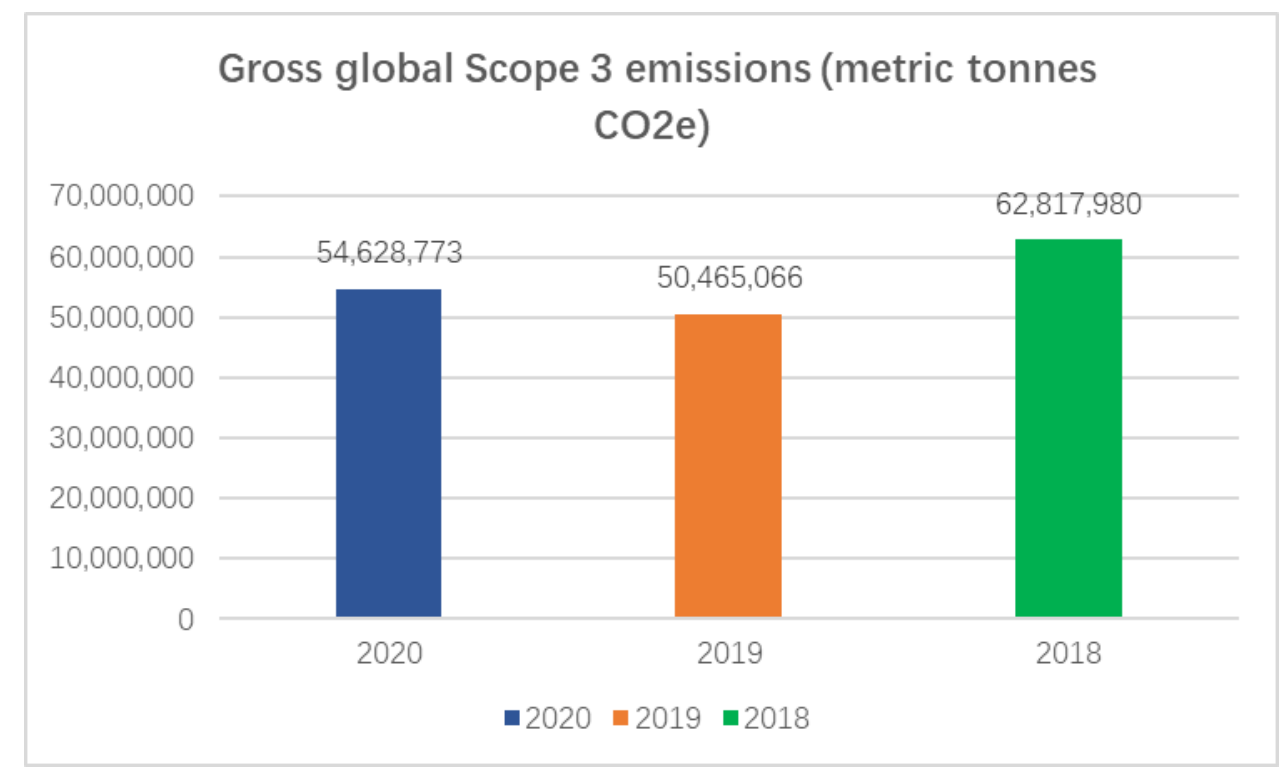

Figure 2. Total gross global Scope 3 emissions 2018-2020 [12-14].

\section{Emissions Reductions}

Energy managers of PepsiCo state annual energy and fuel reduction performance targets, which are aligned with the achievement of their long-term sustainability agenda. In the CDP climate questionnaire, PepsiCo has identified a range of inherent climate-related risks and opportunities that can potentially lead to financial or strategic impact on the business and implemented various emissions reduction initiatives at different stages of the value chain [12].

\subsection{More Efficient Production and Distribution Processes}

PepsiCo is continuously investing in energy efficiency and emission mitigation strategies to improve the efficiency of its manufacturing and fleet operations towards the goal of reducing Scope 1 and Scope 2 emissions. The Resource Conservation (ReCon) program of PepsiCo aims to improve the efficiency of energy, water and waste use in manufacturing processes and seeks feasible and effective ways to reduce fuel and electricity consumption in operations by taking advantage of training and technology (Table 4). As an important component of the climate risk assessment, PepsiCo assesses the risks of new technologies needed to adapt to climate change in the future (including electric vehicles, efficient computing and cooling infrastructure, efficient manufacturing with less water and material waste). In addition, PepsiCo's R\&D team, which focuses on external innovation, closely monitors technological developments. Any upcoming technological advances that will help PepsiCo achieve its goals are evaluated and discussed internally so that appropriate action can be taken [12].

\subsection{Use of Lower-Emission Sources of Energy}

PepsiCo integrates low carbon options into its prioritised energy procurement strategy, coupled with continued investment in low-carbon technologies in their operations to further progress toward the goal of mitigating absolute emissions across the global value chain by $75 \%$ by 2030 (2015 baseline). In order to achieve the transition to $100 \%$ renewable electricity in the U.S direct operations, PepsiCo has developed a series of solutions. In 2020, PepsiCo will mainly use the Renewable Energy Certificate (REC) to purchase from various projects supporting renewable energy green power generation (Table 5). In the next half decade, PepsiCo plans to sign multi-year power purchase agreements (PPA) to fund the development of renewable power projects, including solar and biogas, as well as 
wind power plants [15]. In 2020, PepsiCo signed several power purchase agreements with renewable power projects as the first step to establish a renewable energy portfolio [12].

Table 4. The financial and emission estimates of improving resource efficiency in 2020 [12].

\begin{tabular}{|c|c|c|c|c|}
\hline $\begin{array}{l}\text { Initiative Category and } \\
\text { Initiative Type }\end{array}$ & $\begin{array}{c}\text { Estimated Annual } \\
\mathrm{CO}_{2} \text { e Savings } \\
(\mathrm{Metric} \text { Tonnes } \\
\mathrm{CO}_{2} \text { e) }\end{array}$ & Scope(s) & $\begin{array}{l}\text { Annual Monetary } \\
\text { Savings (US \$) }\end{array}$ & $\begin{array}{c}\text { Investment } \\
\text { Required (US \$) }\end{array}$ \\
\hline Energy efficiency in buildings & & Scope 1 & & \\
\hline $\begin{array}{l}\text { Combined heat and } \\
\text { power (cogeneration) }\end{array}$ & 7810 & $\begin{array}{c}\text { Scope } 2 \\
\text { (market-based) }\end{array}$ & $2,268,598$ & $11,791,772$ \\
\hline Energy efficiency in buildings & & Scope 1 & & \\
\hline $\begin{array}{l}\text { Heating, Ventilation and Air } \\
\text { Conditioning (HVAC) }\end{array}$ & 2128 & $\begin{array}{c}\text { Scope } 2 \\
\text { (market-based) }\end{array}$ & 421,567 & $2,149,012$ \\
\hline $\begin{array}{l}\text { Energy efficiency in buildings } \\
\text { Insulation }\end{array}$ & 1948 & $\begin{array}{c}\text { Scope } 1 \\
\text { Scope } 2 \\
\text { (market-based) }\end{array}$ & 166,485 & 790,151 \\
\hline $\begin{array}{l}\text { Energy efficiency in buildings } \\
\text { Lighting }\end{array}$ & 1023 & $\begin{array}{c}\text { Scope } 2 \\
\text { (market-based) }\end{array}$ & 169,534 & 990,453 \\
\hline $\begin{array}{l}\text { Energy efficiency in production } \\
\text { processes Compressed air }\end{array}$ & 2633 & $\begin{array}{l}\text { Scope } 2 \\
\text { (market-based) }\end{array}$ & 262,631 & $1,356,136$ \\
\hline $\begin{array}{l}\text { Energy efficiency in production } \\
\text { processes Cooling technology }\end{array}$ & 2223 & $\begin{array}{c}\text { Scope } 1 \\
\text { Scope } 2 \\
\text { (market-based) }\end{array}$ & 252,610 & $1,343,917$ \\
\hline $\begin{array}{l}\text { Energy efficiency in production } \\
\text { processes Fuel switch }\end{array}$ & 583 & Scope 1 & 33,617 & 167,436 \\
\hline $\begin{array}{l}\text { Energy efficiency in production } \\
\text { processes Machine/equipment } \\
\text { replacement }\end{array}$ & 6305 & Scope 1 & 907,884 & $5,397,549$ \\
\hline $\begin{array}{l}\text { Energy efficiency in production } \\
\text { processes Process optimization }\end{array}$ & 18,106 & $\begin{array}{c}\text { Scope } 1 \\
\text { Scope } 2 \\
\text { (market-based) } \\
\text { Scope } 3\end{array}$ & $2,862,834$ & $12,139,619$ \\
\hline $\begin{array}{l}\text { Energy efficiency in production } \\
\text { processes Smart control system }\end{array}$ & 7903 & $\begin{array}{c}\text { Scope } 1 \\
\text { Scope } 2 \\
\text { (market-based) }\end{array}$ & 292,924 & $1,918,890$ \\
\hline $\begin{array}{l}\text { Energy efficiency in production } \\
\text { processes Waste heat recovery }\end{array}$ & 4333 & Scope 1 & 577,112 & $2,841,703$ \\
\hline Total & 54,995 & & $8,215,796$ & $40,886,638$ \\
\hline
\end{tabular}

Table 5. The financial and emission estimates of using low-carbon energy in 2020 [12].

\begin{tabular}{|c|c|c|c|c|}
\hline $\begin{array}{l}\text { Initiative Category and } \\
\text { Initiative Type }\end{array}$ & $\begin{array}{c}\text { Estimated Annual } \\
\mathrm{CO}_{2} \text { e Savings } \\
\text { (Metric Tonnes } \\
\mathrm{CO}_{2} \text { e) }\end{array}$ & Scope(s) & $\begin{array}{c}\text { Annual } \\
\text { Monetary } \\
\text { Savings (US \$) }\end{array}$ & $\begin{array}{c}\text { Investment } \\
\text { Required (US \$) }\end{array}$ \\
\hline $\begin{array}{c}\text { Low-carbon energy } \\
\text { consumption } \\
\text { Biogas }\end{array}$ & 484 & Scope 1 & 377,830 & $1,698,000$ \\
\hline $\begin{array}{l}\text { Low-carbon energy } \\
\text { generation }\end{array}$ & 120 & $\begin{array}{c}\text { Scope } 1 \\
\text { Scope } 2 \\
\text { (market-based) }\end{array}$ & 14,104 & 65,706 \\
\hline $\begin{array}{c}\text { Low-carbon energy } \\
\text { generation } \\
\text { Solar PV }\end{array}$ & 10,873 & $\begin{array}{c}\text { Scope } 2 \\
\text { (market-based) }\end{array}$ & $2,252,856$ & $12,811,075$ \\
\hline Total & 11,477 & & $2,644,790$ & $14,574,781$ \\
\hline
\end{tabular}

\subsection{Development of New Products or Services through RED and Innovation}

In 2019, PepsiCo preliminarily introduced a climate strategy into their product innovation process. In 2020, PepsiCo completed the global rollout of the program and began business integration with its cross-functional partners. The program incorporating a toolkit and business processes aims to improve the capacity within each function of product innovation (e.g., R\&D, marketing, and insights) to identify the potential impacts of product design and production on environmental and climate and adopt sustainable alternatives (Table 6). Sustainable packaging objectives include researching recyclability solutions and incorporating recyclable content into product packaging; improving product specifications to move towards increasingly energy efficient vending and cooling machines being deployed in the marketplace [15]. PepsiCo has joined the NaturAll Bottle Alliance with peer companies to promote the development of renewable bio-based materials for plastic bottles [7]. 
Table 6. The financial and emission estimates of waste reduction and material circularity in 2020 [7].

\begin{tabular}{|c|c|c|c|c|}
\hline $\begin{array}{l}\text { Initiative Category and } \\
\text { Initiative Type }\end{array}$ & $\begin{array}{c}\text { Estimated Annual } \\
\mathrm{CO}_{2} \text { e Savings } \\
(\text { Metric Tonnes } \\
\mathrm{CO}_{2} \text { e) }\end{array}$ & Scope(s) & $\begin{array}{l}\text { Annual } \\
\text { Monetary } \\
\text { Savings }\end{array}$ & $\begin{array}{l}\text { Investment } \\
\text { Required }\end{array}$ \\
\hline $\begin{array}{l}\text { Waste reduction and } \\
\text { material circularity } \\
\text { Product/component/ } \\
\text { material recycling }\end{array}$ & 190,958 & Scope 3 & 0 & 0 \\
\hline $\begin{array}{c}\text { Waste reduction and } \\
\text { material circularity } \\
\text { Product/component/ } \\
\text { material reuse }\end{array}$ & 172,844 & Scope 3 & 0 & 0 \\
\hline Total & 363,802 & & 0 & 0 \\
\hline
\end{tabular}

By comparing the three major emissions reduction initiatives above, waste reduction and material circularity contribute the most significant amount of carbon saving of Scope 3. Minimal investment is required to implement this initiative. Internal incentives and recognition programs motivate employee engagement in emissions reduction initiatives, which is driven by the company's Sustainable Agenda and is also leveraged by the Resource Conservation (ReCon) training program.

Improving resource efficiency requires massive capital investment in multiple companywide sectors and long-term collaborative monitoring and adjustment. However, this initiative also provides economic benefits by contributing to remarkable monetary savings in the reporting year.

\section{Performance Appraisal}

Table 7 reflects the progress PepsiCo has made towards the Sustainable Development Goals announced since 2016. PepsiCo is actively reviewing and updating the methodology for calculating the indicators described in its sustainability report. More advanced data availability or methodological adjustments can change metrics reported for prior periods. PepsiCo has enhanced their calculation methodology since 2019. The baseline years 2015, 2019, 2020 and 2021, have been recalculated utilizing this enhanced methodology [16].

Table 7. Absolute emissions targets and progress made against the targets [12,16].

\begin{tabular}{cccccccc}
\hline & $\mathbf{2 0 1 6}$ & $\mathbf{2 0 1 7}$ & $\mathbf{2 0 1 8}$ & $\mathbf{2 0 1 9}$ & $\mathbf{2 0 2 0}$ & $\mathbf{2 0 2 1}$ & $\mathbf{2 0 3 0}$ Target \\
\hline Scope 1 and 2 (versus 2015 baseline) & $1 \%$ & $4 \%$ & $6 \%$ & $9 \%$ & $23 \%$ & $31 \%$ & $75 \%$ \\
Scope 3 (versus 2015 baseline) & & & $3 \%$ & $2 \%$ & $3 \%$ & $7.9 \%$ & $40 \%$ \\
\hline
\end{tabular}

PepsiCo also announced other two climate-related targets that were active in 2020 and reported the progress towards these targets in the 2021 CDP climate questionnaire. PepsiCo joined RE100 in 2020 and is committed to sourcing 100\% renewable electricity for company-owned operations by 2030 and for their franchise bottlers and third-party manufacturers by 2040 [12]. In 2020, 54.9\% of energy consumption in the company-owned fleet as well as manufacturing is sourced from renewable energy. Further, $50 \%$ of the target has been achieved compared with the $9 \%$ in the base year (2019) [12].

In early 2021, PepsiCo announced a new goal of achieving net-zero emissions by 2040. They are monitoring the guidelines currently being developed by SBTi and will adjust their targets and strategies accordingly. This net-zero target is linked to the absolute emission target to reduce Scope 1, 2 and 3 emissions [12].

In 2020, PepsiCo continued with expanding the investment on building the capacity and upgrading equipment to more efficient and low-carbon options [15]. Pursuing the goal of converting U.S. direct operations to $100 \%$ renewable energy has helped Pepsi achieved a 23\% reduction in Scope 1 and Scope 2 emissions against the 2015 baseline. This achievement exceeded their previous target of a $20 \%$ reduction by 2030 and represents approximately $31 \%$ of the ambitious new target of achieving a 75\% reduction in Scope 1 and 
Scope 2 emissions by 2030. This outstanding progress is also partly due to improvements in efficient lighting, building management systems, solar PV, and cogeneration plants $[9,10,15]$. PepsiCo has made significant progress in the transformation of the manufacturing site. The implementation of zero and near-zero emissions freight technologies has reduced the Modesto site fleet's absolute GHG emissions by more than half (53\%), or 2,790 metric tons of absolute GHG emissions, as well as lowering fleet diesel usage by $78 \%[14,16]$.

The large magnitude of the Scope 3 emissions in the supply chain can provide opportunities for the company to make these reductions more easily achievable [17]. PepsiCo declared that the improvements in retail vending and cooler equipment contributed significantly to the reduction of Scope 3 emissions in 2020. Reducing GHG emissions by more than $50 \%$ in 2020 compared to 2015, while saving approximately 3.6 billion kWh of energy compared to 2015. In addition, PepsiCo is committed to developing sustainable agriculture and encouraging suppliers to undertake a range of agricultural management practices with climate change mitigation and adaptation benefits [15]. PepsiCo noted the positive impact of their efforts in sustainable agriculture in 2020 and the fluctuation in purchases compared to 2019 on Scope 3 emissions associated with agriculture. They developed a custom emission factor for RSPO certified palm oil and compared it to non-certified palm oil to examine the climate impact of this initiative. Since 2015, PepsiCo has achieved approximately 500,000 metric tonnes of emission reductions from palm oil purchases. Between 2018-2020, the emission factors associated with these sustainable agriculture projects decreased by $24 \%$ as a result of their efforts on implementing the Sustainable Sourcing Program (SSP). PepsiCo is also achieving Scope 3 reductions by reducing added sugar in beverages and working towards near-zero waste going from their facilities to landfills [10].

Numerous food companies around the world are also engaged in emission reduction activities and disclosing their emission reduction targets. Nestlé announced an ambitious science-based target to reduce Scope 1 and Scope 2 emissions per tonne of product by 2020 (versus 2010). The company exceeded the goal by the end of 2020, achieving a $37 \%$ reduction [18]. Coca-Cola has achieved its absolute target to reduce their total GHG emissions by $25 \%$ in 2020 [19]. Tyson Foods committed to reducing greenhouse gases (GHG) $30 \%$ by 2030, however, the Scope 1 and Scope 2 emissions in 2020 were still increasing against the 2016 level. The company is considering updating greenhouse gas baselines in response to the expansion of operations in recent years and re-setting the energy and emissions reduction targets [20]. In comparison with other food companies, PepsiCo shows a good performance on tackling its climate and emission reduction goals among the average level of marketplace.

PepsiCo declared that they have a rigorous and transparent process to collect activity data and calculate emissions. All the estimates disclosed in their Sustainability reporting are aligning with the framework of GHG Protocol standards. The detailed standard, protocol, or methodology used in the calculation of the estimates are presented and any exclusion of source of emission in the disclosure is clearly explained [12].

\section{Conclusions and Recommendation}

PepsiCo reported that more than $90 \%$ of their emissions come from Scope 3 activities, including raw material procurement, packaging, and logistics, whereas Scope 1 and Scope 2 emissions mainly come from energy consumption generated during the product manufacturing process. The ambitious goals require the company to make significant changes across their value chain. Although PepsiCo has made great progress in addressing climate issues and reducing carbon emissions towards its climate goals, the company must have a deeper insight of intensifying sustainability challenges, risks, and opportunities it is facing and make greater efforts. In future sustainability reporting, PepsiCo should explicitly identify any areas where goals have not been reached; determine why these goals have not been met and outline targeted actions that need to be taken to bridge the gap between strategy and execution in order to achieve better carbon management. Actions and strategies for the next step can include further planning of accurate emission reduction actions and measures and 
timely adjustment of strategies based on relevant progress, incorporating the establishment of short-term and long-term climate-related targets; improving the risk and opportunity assessment framework to enhance the adaptivity and resilience of various sectors to respond to future climate risk; improve and adopt more advanced science-based research and analysis methodologies; intensify the training of professional and management talents in all fields related to the business; maximise the transparency and quality of financial and emission estimates; launch a feasible supply chain climate programme to expand the engagement of stakeholders, suppliers and consumers and improve decision-making and coordination mechanisms.

This case study also has the potential to be used by stakeholders and peers to evaluate the performance of carbon management of other firms committed to achieving carbon reduction targets. Different firms should set scientific carbon emission reduction targets by incorporating their characteristics. The company's emission reduction targets and roadmap should be refined into those of each department; improving the enthusiasm for emission reduction in each internal operational section by developing environmental key performance indicators; incorporating the carbon emission indicators for upstream materials of the supply chain into the assessment and evaluation of suppliers and providing a decision-making basis for the selection of the suppliers. In terms of information disclosure, firms should establish a reasonable information disclosure system, which should comply with the reporting disclosure requirements stipulated by the government or the market and refer to relevant international standards. Firms can also respond to the concerns of the market and relevant stakeholders by utilising a variety of disclosure forms to present a comprehensive picture of their financial and reduction estimates.

Author Contributions: Conceptualization, D.Q.; writing—original draft preparation, D.Q.; supervision— P.D.; writing — drafting and editing; project administration-G.H. All authors have read and agreed to the published version of the manuscript.

Funding: This research received no external funding.

Institutional Review Board Statement: Not applicable.

Informed Consent Statement: Not applicable.

Data Availability Statement: Not applicable.

Conflicts of Interest: The authors declare no conflict of interest.

\section{Appendix A}

Table A1. Example of methods and formulas for calculating Scope 3 emissions.

\begin{tabular}{lll}
\hline Source & $\begin{array}{l}\text { Emissions Calculation } \\
\text { Methodology }\end{array}$ & Calculation Formula \\
\hline Purchased goods and services & $\begin{array}{l}\text { Using procurement data and } \\
\text { material-specific } \\
\text { emission factors. }\end{array}$ & $\begin{array}{l}\text { Total emissions of purchased goods are calculated as follows: } \\
\sum(\text { quantities of good purchased }(\mathrm{e} . \mathrm{g} ., \mathrm{kg}) \times \mathrm{supplier-specific} \\
\text { emission factor of purchased good or service }(\mathrm{e} . \mathrm{g} ., \mathrm{kg} \\
\left.\left.\mathrm{CO}_{2} \mathrm{e} / \mathrm{kg}\right)\right)\end{array}$ \\
\hline & $\begin{array}{l}\text { Using spend data on capital } \\
\text { goods and EPA's Extended } \\
\text { Economic Input Output } \\
\text { (EEIO) methodology } \\
\text { emission factors. }\end{array}$ & $\begin{array}{l}\text { Total emissions of capital goods are calculated as follows: } \\
\left.\text { per unit of economic value }\left(\mathrm{kg} \mathrm{CO} \mathrm{CO}_{2} \mathrm{e} / \$\right)\right)\end{array}$ \\
\hline
\end{tabular}


Table A1. Cont.

\begin{tabular}{|c|c|c|}
\hline Source & $\begin{array}{l}\text { Emissions Calculation } \\
\text { Methodology }\end{array}$ & Calculation Formula \\
\hline \multirow{8}{*}{$\begin{array}{l}\text { Fuel-and-energy-related } \\
\text { activities (not included in } \\
\text { Scope } 1 \text { or } 2 \text { ) }\end{array}$} & \multirow{8}{*}{$\begin{array}{l}\text { Using actual fuel use data in } \\
\text { our internal operations and } \\
\text { using DEFRA upstream } \\
\text { emission factors. }\end{array}$} & (a) Upstream emissions of purchased fuels \\
\hline & & $\begin{array}{l}\text { sum across each fuel type consumed: } \\
\left.\sum \text { (fuel consumed (e.g., } \mathrm{kWh}\right) \\
\left.\times \text { upstream fuel emission factor }\left(\mathrm{kg} \mathrm{CO}_{2} \mathrm{e}\right) / \mathrm{kWh}\right) \text { ) where: } \\
\text { upstream fuel emission factor }=\text { life cycle emission } \\
\text { factor-combustion emission factor. }\end{array}$ \\
\hline & & (b) Upstream emissions of purchased electricity \\
\hline & & $\begin{array}{l}\text { sum across suppliers, regions, or countries: } \\
\sum(\text { electricity consumed }(\mathrm{kWh}) \times \text { upstream electricity emission } \\
\text { factor }(\mathrm{kgCO} 2 \mathrm{e}) / \mathrm{kWh}))+(\text { steam consumed }(\mathrm{kWh}) \times \text { upstream } \\
\left.\left.\text { steam emission factor }\left(\mathrm{kg} \mathrm{CO} \mathrm{CO}_{2} \mathrm{e}\right) / \mathrm{kWh}\right)\right)+(\text { heating consumed } \\
\left.\left.(\mathrm{kWh}) \times \text { upstream heating emission factor }\left(\mathrm{kg} \mathrm{CO}_{2} \mathrm{e}\right) / \mathrm{kWh}\right)\right)+ \\
(\text { cooling consumed }(\mathrm{kWh}) \times \text { upstream cooling emission factor } \\
(\mathrm{kg} \mathrm{CO} 2 \mathrm{e}) / \mathrm{kWh})) \\
\text { where: upstream emission factor }=\text { life cycle emission } \\
\text { factor-combustion emissions factor-T\&D losses }\end{array}$ \\
\hline & & (c) Transmission and distribution (T\&D) losses \\
\hline & & $\begin{array}{l}\text { sum across suppliers, regions, or countries: } \\
\sum \text { (electricity consumed }(\mathrm{kWh}) \times \text { electricity life cycle emission } \\
\left.\text { factor }\left(\left(\mathrm{kg} \mathrm{CO} \mathrm{CO}_{2} \mathrm{e}\right) / \mathrm{kWh}\right) \times \mathrm{T} \& \mathrm{D} \text { loss rate }(\%)\right)+(\text { steam } \\
\text { consumed }(\mathrm{kWh}) \times \text { steam life cycle emission factor }\left(\left(\mathrm{kg} \mathrm{CO} \mathrm{CO}_{2}\right.\right. \\
\mathrm{e}) / \mathrm{kWh}) \times \mathrm{T} \& \mathrm{D} \text { loss rate }(\%))+(\text { heating consumed }(\mathrm{kWh}) \times \\
\text { heating life cycle emission factor }\left(\left(\mathrm{kg} \mathrm{CO} \mathrm{CO}_{2} \mathrm{e}\right) / \mathrm{kWh}\right) \times \mathrm{T} \& \mathrm{D} \text { loss } \\
\text { rate }(\%))+(\text { cooling consumed }(\mathrm{kWh}) \times \text { cooling life cycle } \\
\text { emission factor }((\mathrm{kg} \mathrm{CO} 2 \mathrm{e}) / \mathrm{kWh}) \times \mathrm{T} \& \mathrm{D} \text { loss rate }(\%))\end{array}$ \\
\hline & & $\begin{array}{l}\text { (d) Generation of purchased electricity that is sold to } \\
\text { end users }\end{array}$ \\
\hline & & $\begin{array}{l}\text { sum across suppliers, regions, or countries: } \\
\sum(\text { electricity purchased for resale }(\mathrm{kWh}) \times \text { electricity life cycle } \\
\left.\left.\text { emission factor }\left(\mathrm{kg} \mathrm{CO}_{2} \mathrm{e}\right) / \mathrm{kWh}\right)\right)+(\text { steam purchased for resale } \\
\left.\left.(\mathrm{kWh}) \times \text { steam life cycle emission factor }\left(\mathrm{kg} \mathrm{CO}_{2} \mathrm{e}\right) / \mathrm{kWh}\right)\right)+ \\
(\text { heating purchased for resale }(\mathrm{kWh}) \times \text { heating life cycle } \\
\left.\left.\text { emission factor }\left(\mathrm{kg} \mathrm{CO} \mathrm{CO}_{2} \mathrm{e}\right) / \mathrm{kWh}\right)\right)+(\text { cooling purchased for } \\
\text { resale }(\mathrm{kWh}) \times \text { cooling life cycle emission factor }\left(\mathrm{kg} \mathrm{CO}_{2}\right. \\
\mathrm{e}) / \mathrm{kWh}))\end{array}$ \\
\hline
\end{tabular}


Table A1. Cont.

\begin{tabular}{|c|c|c|}
\hline Source & $\begin{array}{l}\text { Emissions Calculation } \\
\text { Methodology }\end{array}$ & Calculation Formula \\
\hline $\begin{array}{l}\text { Upstream transportation and } \\
\text { distribution }\end{array}$ & $\begin{array}{l}\text { Using a combination of actual } \\
\text { miles and weight moved data } \\
\text { and using EPA Smartway } \\
\text { transportation emission } \\
\text { factors as well as spend data } \\
\text { and EPA EEIO methodology } \\
\text { emission factors. }\end{array}$ & 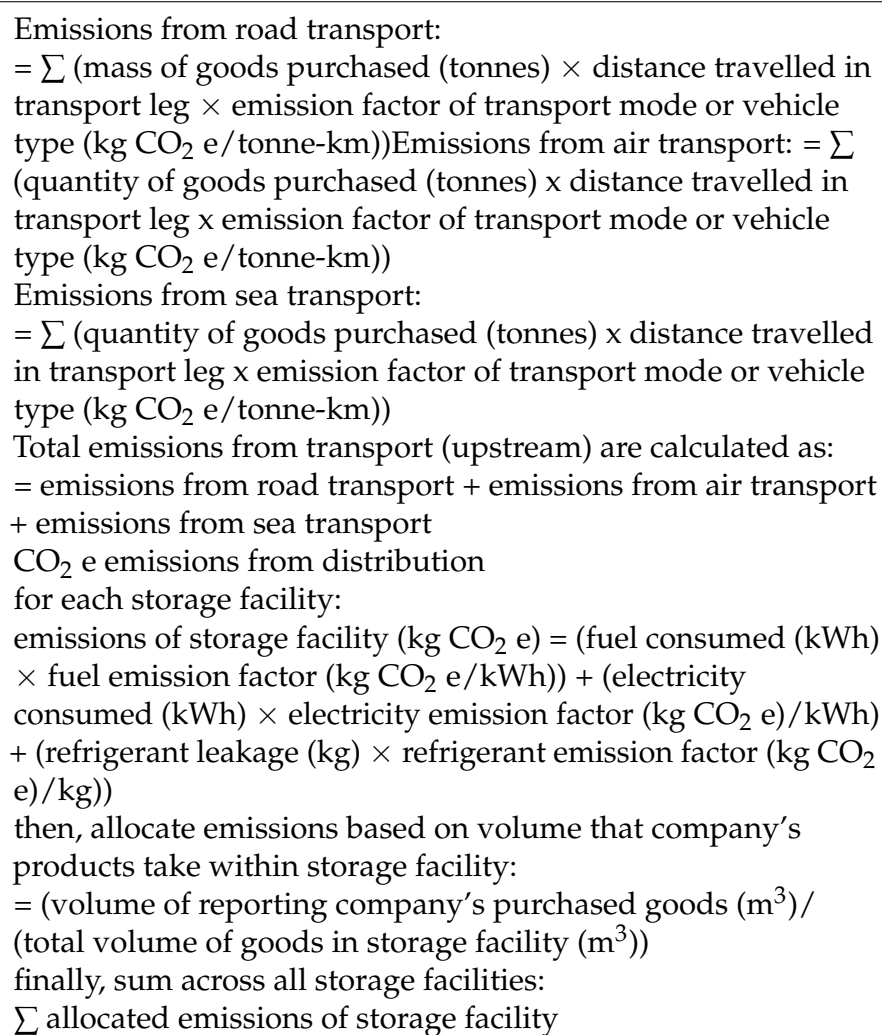 \\
\hline
\end{tabular}

Using waste generated and disposal methods that we

Waste generated in operations keep track of internally and EPA WARM Tool waste emission factors.
Sum across waste treatment methods:

$\sum$ (total mass of waste (tonnes) $\times$ proportion of total waste being treated by waste treatment method $\times$ emission factor of waste treatment method $\left(\mathrm{kg} \mathrm{CO}_{2} \mathrm{e} /\right.$ tonne $\left.)\right)$
Using internal employee air travel data obtained from various systems around the globe and EPA emission

Business travel factors for air travel. Rental car data obtained from suppliers or internal time and expense reports were used along with EPA EEIO emission factors.
$\mathrm{CO}_{2}$ e emissions from business travel Sum across vehicle types:

$\sum$ (distance travelled by vehicle type (vehicle-km or passenger-km) $\times$ vehicle specific emission factor $\left(\mathrm{kg} \mathrm{CO}_{2}\right.$ $\mathrm{e} /$ vehicle-km or $\mathrm{kg} \mathrm{CO}_{2} \mathrm{e} /$ passenger-km)) + (optional) $\sum$ (annual number of hotel nights (nights) $\times$ hotel emission factor (kg CO 2 e/night))

Calculating emissions from employee travel using the distance-based method the total distance travelled by rail $(\mathrm{km})$ is calculated as: $\sum$ (daily one way distance between home and work $(\mathrm{km}) \times 2 \times$ $5 \times$ number of commuting weeks per year) the total distance travelled by car $(\mathrm{km})$ is calculated as:

Using employee headcoun data and estimations of

Employee commuting commuting modes, distances and annual working days and DEFRA emission factors. $\sum$ (daily one way distance between home and work $(\mathrm{km}) \times 2 \times$

$5 \times$ number of commuting weeks per year)

Total emissions from employee commuting for the reporting year is calculated as:

$\sum$ (total distance travelled by vehicle type (vehicle-km or passenger-km) $\times$ vehicle specific emission factor $(\mathrm{kg} \mathrm{CO} 2$ $\mathrm{e} /$ vehicle- $\mathrm{km}$ or $\mathrm{kg} \mathrm{CO}_{2} \mathrm{e}$ /passenger-km)) 
Table A1. Cont.

\begin{tabular}{|c|c|c|}
\hline Source & $\begin{array}{l}\text { Emissions Calculation } \\
\text { Methodology }\end{array}$ & Calculation Formula \\
\hline Processing of sold products & $\begin{array}{l}\text { Using information on the } \\
\text { volume of products } \\
\text { manufactured by co-packers } \\
\text { and an estimation of fuel and } \\
\text { energy used based on } \\
\text { company-owned KPIs on } \\
\text { energy use per unit } \\
\text { production and IEA electricity } \\
\text { grid factors and DEFRA fuel } \\
\text { emission factors. }\end{array}$ & $\begin{array}{l}\text { Emissions from fuel consumed: } \\
\sum \text { (quantity of fuel consumed (e.g., litre) } \times \text { emission factor for } \\
\left.\text { fuel source }\left(\text { e.g., } \mathrm{kg} \mathrm{CO}_{2} \mathrm{e} / \text { litre }\right)\right) \\
\text { Emissions from electricity consumed: } \\
\sum(\text { quantity of electricity consumed }(\mathrm{e} . \mathrm{g} ., \mathrm{kWh}) \times \text { emission } \\
\text { factor for electricity }(\mathrm{e} . \mathrm{g} ., \mathrm{kg} \mathrm{CO} 2 \mathrm{e} / \mathrm{kWh})) \\
\text { Emissions from waste output: } \\
\sum(\text { mass of waste output }(\mathrm{kg}) \times \text { emission factor for waste } \\
\left.\text { activity }\left(\mathrm{kg} \mathrm{CO} \mathrm{CO}_{2} \mathrm{e} / \mathrm{kg}\right)\right) \\
\text { Total emissions from processing of sold intermediate products }= \\
\text { emissions from fuel }+ \text { emissions from electricity }+ \text { emissions } \\
\text { from waste }\end{array}$ \\
\hline
\end{tabular}

\section{References}

1. IPCC. Special Report-Global Warming of $1.5^{\circ} \mathrm{C}$. Available online: https://www.ipcc.ch/sr15/ (accessed on 8 September 2021).

2. Rogelj, J.; Geden, O.; Cowie, A.; Reisinger, A. Net-Zero Emissions Targets Are Vague: Three Ways to Fix. Nature 2021, 591, 365-368. [CrossRef] [PubMed]

3. Fankhauser, S.; Smith, S.; Allen, M.; Axelsson, K.; Hale, T.; Hepburn, C.; Kendall, J.; Khosla, R.; Lezaun, J.; Mitchell-Larson, E.; et al. The Meaning of Net Zero and how to Get it Right. Nat. Clim. Chang. 2021, 12, 15-21. [CrossRef]

4. UNCC. The Paris Agreement. Available online: https://unfccc.int/process-and-meetings/the-paris-agreement/the-parisagreement (accessed on 8 September 2021).

5. Davis, S.J.; Lewis, N.S.; Shaner, M.; Aggarwal, S.; Arent, D.; Azevedo, I.L.; Benson, S.M.; Bradley, T.; Brouwer, J.; Chiang, Y.-M.; et al. Net-Zero Emissions Energy Systems. Sci. Am. Assoc. Adv. Sci. 2018, 360, 1419. [CrossRef] [PubMed]

6. Harangozo, G.; Szigeti, C. Corporate Carbon Footprint Analysis in Practice-With a Special Focus on Validity and Reliability Issues. J. Clean. Prod. 2017, 167, 1177-1183. [CrossRef]

7. Demaria, S.; Rigot, S. Corporate Environmental Reporting: Are French Firms Compliant with the Task Force on Climate Financial Disclosures' Recommendations? Bus. Strategy Environ. 2021, 30, 721-738. [CrossRef]

8. Caldecott, B. Stranded Assets and the Environment Risk, Resilience and Opportunity, 1st ed.; Routledge: London, UK, $2018 ;$ p. 16.

9. PepsiCo. 2020 Sustainability Report. Available online: https://www.pepsico.com/sustainability-report/strategy (accessed on 8 September 2021).

10. PepsiCo. Climate Change. Available online: https://www.pepsico.com/esg-topics-a-z/climate-change (accessed on 13 September 2021).

11. The Climate Pledge. Net Zero Carbon by 2040. Available online: https://www.theclimatepledge.com/ (accessed on 7 September 2021).

12. PepsiCo, Inc. CDP Climate Change Questionnaire 2021. Available online: https://www.pepsico.com/docs/album/esg-topicspolicies / 2021-cdp-climate-response.pdf (accessed on 11 September 2021).

13. PepsiCo, Inc. CDP Climate Change Questionnaire 2019. Available online: https:/ /www.pepsico.com/docs/album/esg-topicspolicies/2019-cdp-climate-response.pdf (accessed on 11 September 2021).

14. PepsiCo, Inc. CDP Climate Change Questionnaire 2020. Available online: https://www.pepsico.com/docs/album/esg-topicspolicies / 2020-cdp-climate-response.pdf (accessed on 11 September 2021).

15. Grubler, A.; Wilson, C.; Bento, N.; Boza-Kiss, B.; Krey, V.; McCollum, D.L.; Rao, N.D.; Riahi, K.; Rogelj, J.; De Stercke, S.; et al. A Low Energy Demand Scenario for Meeting the $1.5^{\circ} \mathrm{C}$ Target and Sustainable Development Goals without Negative Emission Technologies. Nat. Energy 2018, 3, 515-527. [CrossRef]

16. PepsiCo. 2020 Sustainability Performance Metrics. Available online: https://www.pepsico.com/docs/album/sustainabilityreport/2020-csr/2020-sustainability-performance-metrics-sheet.pdf (accessed on 7 September 2021).

17. EPA. Managing Supply Chain Greenhouse Gas Emissions-Lessons Learned for the Road Ahead. Available online: https: / / www.epa.gov/sites/default/files/2015-07/documents/managing_supplychain_ghg.pdf (accessed on 7 September 2021).

18. Nestlé. Accelerate, Transform, Regenerate: Nestlé's Net Zero Roadmap. Available online: https://www.nestle.com/sites/ default/files / 2021-03/creating-shared-value-report-2020-en.pdf (accessed on 16 September 2021).

19. Coca-Cola 2020 Business \& Environmental, Social and Governance Report. Available online: https:/ / www.coca-colacompany. $\mathrm{com} /$ content/dam/journey/us/en/reports/coca-cola-business-environmental-social-governance-report-2020.pdf (accessed on 16 September 2021).

20. Tyson Foods. Progress: Protecting Our Planet Conserving Natural Resources. Tyson 2020 Sustainability Progress Report. Available online: https:/ / www.tysonsustainability.com/progress-report/progress/natural-resources (accessed on 16 September 2021). 